\title{
Kluster Tanaman Pangan Unggulan di Provinsi Jawa Tengah
}

\author{
Choiroel Woestho ${ }^{1,}$, Milda Handayani ${ }^{2}$, Adi Wibowo N. Fikri ${ }^{3}$ \\ ${ }^{1}$ Fakultas Ekonomi dan Bisnis; Universitas Bhayangkara Jakarta Raya; Jl. Harsono RM \\ Dalam No.46, RT.7/RW.4, Ragunan, Kec. Ps. Minggu, Kota Jakarta Selatan, (021) 7231948; e- \\ mail: choiroel@dsn.ubharajaya.ac.id, milda.handayani@ubharajaya.ac.id, \\ adi.noor@dsn.ubharajaya.ac.id \\ * Korespondensi: e-mail: choiroel@dsn.ubharajaya.ac.id \\ Submitted: 08/10/2020; Revised: 16/12/2020; Accepted: 5/01/2021; Published: 15/01/2021
}

\begin{abstract}
The food crop sector has an important role for regions in Indonesia. Food plants can be a determinant for an area in meeting the needs of the people in that area. In addition, the food crop sector, if developed, can become revenue for the region. This study aims to analyze the leading food plants in 35 districts / cities in Central Java Province. By using the location quotient (LQ) method and the Regional Specialization Index. The data used is time series data from 2014 to 2019 in 35 districts / cities in Central Java Province for food crops based on land area and production. The results obtained for the average $L Q$ value of food crops based on land area, there are only 12 districts / cities which are the basis for superior food crops with Wonogiri Regency at the top. Meanwhile, based on the average $L Q$ value based on production, only 11 districts / cities are the basis for superior food crops with Semarang Regency being the top. For the specialization index based on both land area and production, there is no Regency / City that specializes in Central Java Province.
\end{abstract}

Keywords: Foodcrop Sector, Location Quotient, Specialization Index, Central Java

\begin{abstract}
Abstrak
Sektor tanaman pangan mempunyai peranan penting bagi daerah di Indonesia. Tanaman pangan dapat menjadi penentu bagi suatu daerah dalam memenuhi kebutuhan masyarakat yang ada di daerah tersebut. Selain itu, sektor tanaman pangan jika dikembangkan dapat menjadi pendapatan bagi daerah. Penelitian ini bertujuan untuk menganalisis tanaman pangan unggulan yang ada di 35 Kabupaten/Kota pada Provinsi Jawa Tengah. Dengan menggunakan metode location quotient (LQ) dan Indeks Spesialisasi Regional. Data yang digunakan adalah data time series selama tahun 2014 hingga tahun 2019 pada 35 Kabupaten/Kota di Provinsi Jawa Tengah untuk tanaman pangan berdasarkan luas lahan dan produksi. Hasil yang diperoleh untuk nilai rata - rata LQ tanaman pangan berdasarkan luas lahan, hanya terdapat 12 Kabupaten/Kota yang menjadi basis bagi tanaman pangan unggulan dengan Kabupaten Wonogiri berada di urutan teratas. Sementara berdasarkan nilai rata - rata LQ berdasarkan produksi, hanya 11 Kabupaten/Kota yang menjadi basis tanaman pangan unggulan dengan Kabupaten Semarang menjadi urutan teratas. Untuk indeks spesialisasi baik berdasarkan luas lahan dan produksi, tidak ada Kabupaten/Kota yang mempunyai spesialisasi terhadap Provinsi Jawa Tengah.
\end{abstract}

Kata kunci: Tanaman Pangan, Indeks Lokalisasi, Indeks Spesialisasi, Jawa Tengah 


\section{Pendahuluan}

Pembangunan pertanian menjadi salah satu bagian dari pembangunan ekonomi yang mempunyai tujuan tidak hanya mengejar tingkat produksi pertanian yang tinggi tetapi juga meningkatkan taraf hidup dan kesejahteraan petani serta menyerap tenaga kerja. Meskipun kontribusi sektor pertanian di suatu negara mengalami penurunan, sektor pertanian tetap mempunyai peran penting dalam menyediakan lapangan kerja yang besar (Tan et al., 2015).

Salah satu sub-sektor dari sektor pertanian yang mempunyai peran penting bagi Indonesia adalah sub-sektor tanaman bahan makan. Sub-sektor tanaman bahan makanan merupakan sub-sektor yang strategis, hal ini dikarenakan selain mampu menyerap tenaga kerja terbesar dalam kegiatan produksi, sub-sektor tanaman bahan makanan juga menghasilkan produk yang menjadi bahan pokok bagi sebagian besar masyarakat Indonesia (Tuminem, 2019).

Beras, yang merupakan salah satu komoditas dari sub-sektor tanaman bahan makanan, tingkat produksi serta konsumsinya hampir 90\% berada di kawasan Asia termasuk Indonesia. Produksi beras yang dilakukan oleh negara produsen sebagian besar digunakan untuk memenuhi kebutuhan dalam negeri. Sementara, volume beras yang diperdagangkan pada umumnya merupakan sisa konsumsi dalam negeri yang jumlahnya sekitar $4 \%-7 \%$ dari total produksi beras dunia (Rohman \& Maharani, 2018). Hal ini yang menyebabkan negara negara konsumen beras termasuk Indonesia perlu menempuh kebijakan kemandirian penyediaan beras dengan cara peningkatan produksi beras domestik sebagai kebijakan pangan nasional.

Berdasarkan data dari Badan Pusat Statistik dan Kementerian Pertanian. Produksi padi tahun 2015 sebanyak 75,40 juta ton gabah kering gilng (GKG) atau mengalami kenaikan sebanyak 4,5 juta ton (6,42 persen) dibandingkan tahun 2014. Kenaikan produksi padi tahun 2015 terjadi di Pulau Jawa sebanyak 2,31 juta ton dan di luar Pulau Jawa sebanyak 2,24 juta ton. Kenaikan produksi terjadi karena kenaikan luas panen seluas 0,32 juta hektar $(2,31$ persen) dan produktivitas sebesar 2,06 kuintal/hektar (4,01 persen).

Produksi kedelai tahun 2015 sebanyak 963,18 ribu ton biji kering, meningkat sebanyak 8,19 ribu ton $(0,86$ persen) dibandingkan tahun 2014 . Peningkatan produksi kedelai tersebut terjadi di luar Pulau Jawa sebanyak 30,50 ribu ton, sementara di Pulau Jawa terjadi penurunan produksi sebanyak 2,31 ribu ton. Peningkatan produksi kedelai terjadi karena kenaikan produktivitas sebesar 0,17 kuintal/hektar (1,10 persen), meskipun luas panen mengalami penurunan seluas 1,59 ribu hektar (0,26 persen). Kenaikan produksi kedelai tahun 2015 yang relatif besar terjadi di Provinsi Nusa Tengara Barat, Sulawesi Selatan, Sulawesi Tengara, Jawa Tengah, dan Sumatera Selatan. Sementara itu, penurunan produksi kedelai tahun 2015 yang relatif besar terjadi di Provinsi Jawa Barat, Aceh, Jawa Timur, Lampung, dan Sulawesi Tengah.

Produksi kacang tanah tahun 2015 sebanyak 605,45 ribu ton bij kering, mengalami penurunan sebanyak 3,45 ribu ton (5,24 persen) dibandingkan tahun 2014 . Penurunan produksi kacang tanah terjadi di luar Pulau Jawa sebanyak 4,51 ribu ton, sementara di Pulau Jawa 
terjadi peningkatan produksi sebanyak 1,07 ribu ton. Penurunan produksi terjadi karena penurunan luas panen seluas 4,9 ribu hektar (9,01 persen) sedangkan produktivitas mengalami kenaikan sebesar 0,54 kuintal/hektar (4,2 persen). Provinsi Jawa Tengah merupakan Provinsi yang terletak di bagian tengah Pulau Jawa. Provinsi Jawa Tengah berbatasan dengan Provinsi Jawa Barat di sebelah barat, Samudra Hindia dan Daerah Istimewa Yogyakarta di sebelah selatan, Jawa Timur di sebelah timur, dan Laut Jawa di sebelah utara. Luas wilayahnya 34.548 $\mathrm{km}^{2}$, atau sekitar $28,94 \%$ dari luas pulau Jawa. Provinsi Jawa Tengah juga meliputi Pulau Nusakambangan di sebelah selatan (dekat dengan perbatasan Jawa Barat), serta Kepulauan Karimun Jawa di Laut Jawa.

Usaha Tani merupakan kemampuan dari petani dalam mengorganisasikan dan mengkoordinir faktor-faktor produksi yang dikuasainya dengan sebaik-baiknya. Dengan demikian petani yang kurang mampu memanfaatkan benih, pupuk, luas lahan, tenaga kerja dan pestisida akan memiliki tingkat pendapatan yang relatif lebih rendah (Oktavia et al., 2015).

Dengan topografi yang berbeda - beda serta beranekaragam, dapat dipastikan produksi tanaman bahan makanan selain beras yang ada di Provinsi Jawa Tengah berbeda pada setiap wilayahnya. Keanekaragaman pada tiap wilayah ini perlu untuk dibuat cluster wilayah yang berdasarkan atas luas lahan serta hasil produksi tanaman bahan makanan. Hal ini dimaksudkan untuk melihat potensi dari tiap - tiap wilayah agar lebih meningkatkan produksi tanaman bahan makanan.

Untuk mengoptimalkan pemanfaatan lahan dengan penanaman beberapa komoditi diperlukan perencanaan usaha tani. Di mana perencanaan usaha tani yang dimaksud adalah pengaturan kembali sumber daya usaha tani melalui penetapan tujuan-tujuan, penyusunan rencana dan program-program dengan menggunakan sumber daya yang terbatas. Bagi seorang petani, perencanaan usaha tani adalah bagaimana seharusnya mengalokasikan sumber daya untuk mencapai tujuan tertentu tetapi juga harus dapat meramalkan bagaimana mengalokasikan sumber daya dengan faktor-faktor tertentu seperti harga, permintaan, teknologi dan sebagainya.

Berdasarkan dari uraian tersebut, maka penelitian yang dilakukan bertujuan untuk (1) mengidentifikasi potensi tanaman bahan makanan pada setiap wilayah di Provinsi Jawa Tengah berdasarkan atas luas lahan serta hasil produksi, serta (2) menyusun cluster wilayah potensi pengembangan tanaman bahan makanan berdasarkan luas produksi serta hasil produksi tanaman bahan makanan.

\section{Metode Penelitian}

Metode pengambilan data yang digunakan dalam penelitian ini berupa data sekunder yang diperoleh dari Biro Pusat Statistik (BPS) Jawa Tengah dan Kementerian Pertanian. Data berupa data time series antara tahun 2014 hingga tahun 2018 pada 35 Kabupaten/Kota di Provinsi Jawa Tengah yang terdiri atas jumlah produksi dan luas lahan tanaman pangan pada 
Kabupaten/Kota di Provinsi Jawa Tengah serta jumlah produksi dan luas lahan tanaman pangan pada Provinsi Jawa Tengah.

Berdasarkan jenis data yang digunakan dalam penelitian, maka desain penelitian dapat digambarkan sebagai berikut:

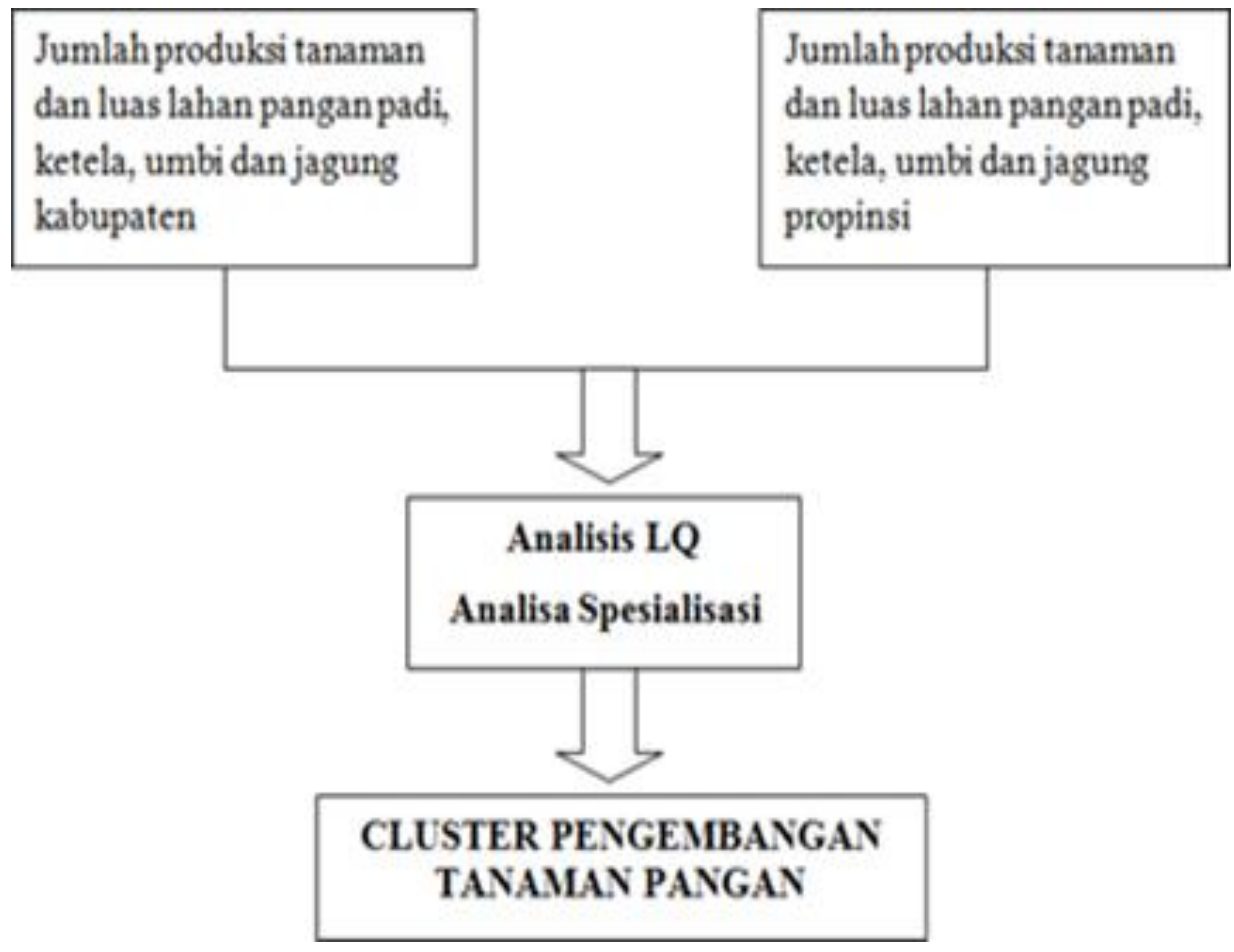

Sumber: Hasil Penelitian (2021)

Gambar 2. Desain Penelitian

Analisis LQ umumnya digunakan untuk menganalisis keunggulan komparatif yang ada pada Kabupaten/Kota dan Provinsi. Analisis LQ pada suatu sektor tertentu dilakukan dengan membandingkan share sektor tertentu - bisa dengan menggunakan nilai output atau jumlah tenaga kerja - terhadap totalnya pada tingkat daerah/lokal dengan share sektor yang sama tersebut terhadap totalnya pada tingkat nasional (sering disebut juga wilayah referensi, yaitu wilayah yang lebih luas dari daerah/lokal yang dianalisa atau supra-daerah (Taufiqurahman \& Widodo, 2011)

Formula sebagai contoh dengan menggunakan nilai output, adalah sebagai berikut :

$$
L Q=\frac{S i R / S R}{S i N / S N}
$$

Dimana:

SiR: Jumlah PDRB sektor I pada daerah $\mathrm{R}$

SR: Jumlah Total PDRB pada daerah $\mathrm{R}$

SiN: Jumlah PDB sektor I pada wilayah nasional

$\mathrm{SN}$ : Jumlah total PDB pada wilayah nasional

Ada tiga kondisi yang dapat dicirikan dalam perhitungan dengan metode pada suatu wilayah, yaitu: 
Jika nilai $>1$, menunjukkan sektor tersebut disamping dapat memenuhi kebutuhannya sendiri, juga memberikan peluang untuk diekspor ke wilayah lainnya. Dapat dikatakan pula bahwa wilayah tersebut terspesialisasi pada sektor yang bersangkutan (sektor tersebut merupakan sektor basis).

Jika nilai $=1$, menunjukkan sektor tersebut hanya dapat memenuhi kebutuhan wilayah itu sendiri. Atau dengan kata lain, sektor yang bersangkutan di daerah tersebut memiliki tingkat spesialisasi yang sama dibandingkan dengan sektor yang sama pada wilayah nasional.

Jika nilai $<1$, menunjukkan bahwa sektor tersebut tidak cukup memenuhi kebutuhan wilayahnya sendiri, sehingga wilayah tersebut harus mengimpor dari wilayah lain. Dapat dikatakan juga bahwa wilayah tersebut tidak terspesialisasi pada sektor yang bersangkutan (sektor tersebut merupakan sektor non basis).

Menurut (Mahroji \& Indrawati, 2020) masyarakat dapat lebih efektif dan efisien jika terdapat pembagian kerja yang membagi keseluruhan proses produksi menjadi unit-unit khusus yang terspesialisasi. Ekonomi spesialisasi telah memungkinkan terbentuknya jaringan perdagangan antarindividu dan antarnegara yang demikian luas, yang merupakan ciri dari suatu perekonomian maju. Adanya keterkaitan ekonomi (spesialisasi) antardaerah yang mendorong proses pertukaran sesuai kebutuhan masing-masing, akan memungkinkan bergeraknya perekonomian masing-masing daerah secara bersama-sama menuju proses pertumbuhan.

Penggunaan alat analisis indeks spesialisasi regional adalah untuk mengetahui tingkat spesialisasi antar daerah di suatu sistem perekonomian. Analisis indeks spesialisasi regional dilakukan dengan menggunakan Indeks Krugman untuk menganalisis spesialisasi regioanl di wilayah Amerika Serikat.

$$
S I_{j k}=\sum_{i=1}^{n}\left|\left(\left(E_{i j}\right) /\left(E_{j}\right)\right)-\left(\left(E_{i k}\right) /\left(E_{k}\right)\right)\right|
$$

Dimana :

$\mathrm{SI}_{\mathrm{jk}}:$ Indeks Spesialisasi Daerah $\mathrm{j}$ dan $\mathrm{k}$

$\mathrm{E}_{\mathrm{jk}}:$ PDRB Sektor i pada Daerah $\mathrm{j}$

$E_{j} \quad$ : Total PDRB Daerah $j$

$\mathrm{E}_{\mathrm{ik}}$ : PDRB Sektor i pada Daerah k

$\mathrm{E}_{\mathrm{k}} \quad$ : Total PDRB Daerah $\mathrm{k}$

Kriteria pengukurannya adalah bahwa bila indeks spesialisasi regional mendekati nilai nol, maka kedua daerah j dan $\mathrm{k}$ tidak memiliki spesialisasi, dan bila indeks spesialisasi regional mendekati nilai dua maka kedua daerah j dan $\mathrm{k}$ memiliki spesialisasi. Batas tengah antara angka nol dan dua tersebut adalah satu, dan oleh karena itu bila suatu sektor memiliki nilai indeks spesialisasi regional yang lebih besar dari satu maka sektor tersebut dapat dianggap sebagai sektor yang memiliki spesialisasi. Untuk melihat tinggi rendahnya tingkat spesialisasi suatu daerah terhadap daerah lainnya, dipergunakan nilai rata-rata indeks spesialisasi regional dari seluruh daerah sebagai pembanding. Bila dalam analisanya menggunakan datanya time 
series, maka kenaikan nilai indeks spesialisasi regional menunjukkan semakin terspesialisasinya suatu sektor/lapangan usaha antar daerah yang bersangkutan.

\section{Hasil dan Pembahasan}

Provinsi Jawa Tengah (Jawa adalah sebuah provinsi Indonesia yang terletak di bagian tengah Pulau Jawa. Ibu kotanya adalah Semarang. Provinsi ini berbatasan dengan Provinsi Jawa Barat di sebelah barat, Samudra Hindia dan Daerah Istimewa Yogyakarta di sebelah selatan, Jawa Timur di sebelah timur, dan Laut Jawa di sebelah utara. Luas wilayahnya 32.548 $\mathrm{km}^{2}$, atau sekitar $28,94 \%$ dari luas pulau Jawa. Provinsi Jawa Tengah juga meliputi Pulau Nusakambangan di sebelah selatan (dekat dengan perbatasan Jawa Barat), serta Kepulauan Karimun Jawa di Laut Jawa.

Tabel 1. Rata - Rata Nilai LQ Tanaman Pangan Kabupaten/Kota di Provinsi Jawa Tengah

Berdasarkan Luas Lahan

\begin{tabular}{|c|c|c|c|c|c|c|c|c|c|c|}
\hline \multirow[b]{2}{*}{ Daerah } & \multicolumn{8}{|c|}{ LQ Luas Lahan } & \multirow{2}{*}{$\begin{array}{c}\text { Rata } \\
- \\
\text { Rata }\end{array}$} & \multirow[b]{2}{*}{ Klasifikas } \\
\hline & $\begin{array}{c}\text { Padi } \\
\text { Sawah }\end{array}$ & $\begin{array}{c}\text { Padi } \\
\text { Ladang }\end{array}$ & Jagung & Kedelai & $\begin{array}{c}\text { Kacang } \\
\text { Tanah }\end{array}$ & $\begin{array}{c}\text { Kacang } \\
\text { Hijau }\end{array}$ & $\begin{array}{l}\text { Ubi } \\
\text { Kayu }\end{array}$ & $\begin{array}{l}\text { Ubi } \\
\text { Jalar }\end{array}$ & & \\
\hline $\begin{array}{l}\text { Kabupaten } \\
\text { Wonogiri }\end{array}$ & 0,45 & 2,86 & 1,17 & 1,40 & 5,17 & 0,02 & 4,80 & 0,16 & 2,00 & Basis \\
\hline $\begin{array}{l}\text { Kabupaten } \\
\text { Semarang }\end{array}$ & 1,06 & 0,51 & 1,09 & 0,26 & 1,30 & 0,00 & 0,65 & 7,12 & 1,50 & Basis \\
\hline $\begin{array}{l}\text { Kabupaten } \\
\text { Wonosobo }\end{array}$ & 0,76 & 0,04 & 1,98 & 0,01 & 0,12 & 0,00 & 2,07 & 6,48 & 1,43 & Basis \\
\hline $\begin{array}{l}\text { Kabupaten } \\
\text { Karanganyar }\end{array}$ & 1,25 & 0,23 & 0,39 & 0,18 & 1,77 & 0,00 & 1,10 & 5,29 & 1,28 & Basis \\
\hline $\begin{array}{l}\text { Kabupaten } \\
\text { Jepara }\end{array}$ & 0,98 & 0,81 & 0,56 & 0,10 & 3,91 & 0,01 & 2,84 & 0,46 & 1,21 & Basis \\
\hline $\begin{array}{l}\text { Kabupaten } \\
\text { Rembang }\end{array}$ & 0,75 & 1,91 & 1,65 & 1,37 & 0,84 & 0,71 & 1,23 & 0,97 & 1,18 & Basis \\
\hline $\begin{array}{l}\text { Kabupaten } \\
\text { Kebumen }\end{array}$ & 1,11 & 1,89 & 0,25 & 1,41 & 0,73 & 2,99 & 0,83 & 0,20 & 1,18 & Basis \\
\hline $\begin{array}{l}\text { Kabupaten } \\
\text { Grobogan }\end{array}$ & 0,66 & 0,49 & 1,97 & 2,86 & 0,09 & 2,80 & 0,08 & 0,06 & 1,13 & Basis \\
\hline $\begin{array}{l}\text { Kabupaten } \\
\text { Demak }\end{array}$ & 1,01 & 1,01 & 0,78 & 0,12 & 0,03 & 5,25 & 0,03 & 0,39 & 1,08 & Basis \\
\hline $\begin{array}{l}\text { Kabupaten } \\
\text { Banjarnegara }\end{array}$ & 0,82 & 0,75 & 1,34 & 0,44 & 1,09 & 0,01 & 3,08 & 0,93 & 1,06 & Basis \\
\hline $\begin{array}{l}\text { Kabupaten } \\
\text { Pati }\end{array}$ & 0,99 & 0,80 & 0,75 & 0,68 & 0,53 & 1,99 & 2,13 & 0,39 & 1,03 & Basis \\
\hline $\begin{array}{l}\text { Kabupaten } \\
\text { Magelang }\end{array}$ & 1,28 & 0,00 & 0,70 & 0,00 & 0,31 & 0,00 & 0,48 & 5,39 & 1,02 & Basis \\
\hline $\begin{array}{l}\text { Kabupaten } \\
\text { Blora }\end{array}$ & 0,79 & 3,23 & 1,76 & 1,07 & 0,38 & 0,26 & 0,19 & 0,23 & 0,99 & Non-Basis \\
\hline Kabupaten & 1,24 & 0,00 & 0,80 & 0,14 & 0,25 & 0,00 & 0,49 & 4,92 & 0,98 & Non-Basis \\
\hline
\end{tabular}




\begin{tabular}{|c|c|c|c|c|c|c|c|c|c|c|}
\hline \multirow[b]{2}{*}{ Daerah } & \multicolumn{8}{|c|}{ LQ Luas Lahan } & \multirow{2}{*}{$\begin{array}{c}\text { Rata } \\
\text { - } \\
\text { Rata }\end{array}$} & \multirow[b]{2}{*}{ Klasifikasi } \\
\hline & $\begin{array}{c}\text { Padi } \\
\text { Sawah }\end{array}$ & $\begin{array}{c}\text { Padi } \\
\text { Ladang }\end{array}$ & Jagung & Kedelai & $\begin{array}{c}\text { Kacang } \\
\text { Tanah }\end{array}$ & $\begin{array}{c}\text { Kacang } \\
\text { Hijau }\end{array}$ & $\begin{array}{l}\text { Ubi } \\
\text { Kayu }\end{array}$ & $\begin{array}{l}\text { Ubi } \\
\text { Jalar }\end{array}$ & & \\
\hline \multicolumn{11}{|l|}{ Batang } \\
\hline $\begin{array}{l}\text { Kabupaten } \\
\text { Boyolali }\end{array}$ & 0,84 & 1,24 & 1,55 & 1,38 & 1,29 & 0,01 & 1,02 & 0,15 & 0,93 & Non-Basis \\
\hline $\begin{array}{l}\text { Kabupaten } \\
\text { Kudus }\end{array}$ & 1,15 & 0,37 & 0,49 & 0,29 & 0,56 & 2,99 & 0,82 & 0,75 & 0,93 & Non-Basis \\
\hline $\begin{array}{l}\text { Kabupaten } \\
\text { Cilacap }\end{array}$ & 1,31 & 1,50 & 0,14 & 1,29 & 0,28 & 0,80 & 0,56 & 0,72 & 0,82 & Non-Basis \\
\hline $\begin{array}{l}\text { Kabupaten } \\
\text { Sragen }\end{array}$ & 1,13 & 1,10 & 0,80 & 1,22 & 1,74 & 0,05 & 0,25 & 0,00 & 0,79 & Non-Basis \\
\hline $\begin{array}{l}\text { Kabupaten } \\
\text { Purworejo }\end{array}$ & 1,28 & 0,32 & 0,24 & 1,17 & 0,68 & 0,80 & 1,06 & 0,70 & 0,78 & Non-Basis \\
\hline $\begin{array}{l}\text { Kabupaten } \\
\text { Sukoharjo }\end{array}$ & 1,32 & 0,00 & 0,15 & 1,16 & 2,74 & 0,02 & 0,47 & 0,02 & 0,74 & Non-Basis \\
\hline $\begin{array}{l}\text { Kabupaten } \\
\text { Kendal }\end{array}$ & 0,85 & 0,24 & 2,02 & 0,62 & 0,32 & 0,36 & 0,15 & 1,28 & 0,73 & Non-Basis \\
\hline $\begin{array}{l}\text { Kabupaten } \\
\text { Temanggung }\end{array}$ & 0,84 & 0,15 & 2,10 & 0,00 & 0,23 & 0,00 & 0,60 & 1,76 & 0,71 & Non-Basis \\
\hline $\begin{array}{l}\text { Kabupaten } \\
\text { Purbalingga }\end{array}$ & 1,17 & 0,19 & 0,72 & 1,35 & 0,28 & 0,00 & 1,16 & 0,74 & 0,70 & Non-Basis \\
\hline Kota Salatiga & 1,28 & 0,00 & 0,48 & 0,07 & 0,05 & 0,00 & 1,58 & 2,12 & 0,70 & Non-Basis \\
\hline $\begin{array}{l}\text { Kabupaten } \\
\text { Banyumas }\end{array}$ & 1,35 & 0,48 & 0,25 & 0,74 & 0,66 & 0,25 & 0,65 & 0,68 & 0,63 & Non-Basis \\
\hline $\begin{array}{l}\text { Kota } \\
\text { Surakarta }\end{array}$ & 1,38 & 1,06 & 0,00 & 0,00 & 1,67 & 0,00 & 0,91 & 0,00 & 0,63 & Non-Basis \\
\hline $\begin{array}{l}\text { Kabupaten } \\
\text { Brebes }\end{array}$ & 1,22 & 0,58 & 0,74 & 0,62 & 0,11 & 0,79 & 0,21 & 0,30 & 0,57 & Non-Basis \\
\hline $\begin{array}{l}\text { Kota } \\
\text { Semarang }\end{array}$ & 1,32 & 0,49 & 0,40 & 0,03 & 0,81 & 0,16 & 0,78 & 0,49 & 0,56 & Non-Basis \\
\hline $\begin{array}{l}\text { Kabupaten } \\
\text { Klaten }\end{array}$ & 1,28 & 0,01 & 0,63 & 1,10 & 0,64 & 0,06 & 0,16 & 0,31 & 0,52 & Non-Basis \\
\hline $\begin{array}{l}\text { Kabupaten } \\
\text { Pemalang }\end{array}$ & 1,38 & 0,41 & 0,42 & 0,49 & 0,10 & 0,02 & 0,18 & 0,64 & 0,45 & Non-Basis \\
\hline $\begin{array}{l}\text { Kabupaten } \\
\text { Pekalongan }\end{array}$ & 1,45 & 0,22 & 0,21 & 0,06 & 0,26 & 0,23 & 0,20 & 0,95 & 0,45 & Non-Basis \\
\hline $\begin{array}{l}\text { Kabupaten } \\
\text { Tegal }\end{array}$ & 1,22 & 0,07 & 1,05 & 0,06 & 0,07 & 0,02 & 0,10 & 0,44 & 0,38 & Non-Basis \\
\hline $\begin{array}{l}\text { Kota } \\
\text { Magelang }\end{array}$ & 1,55 & 0,00 & 0,01 & 0,00 & 0,08 & 0,00 & 0,09 & 0,00 & 0,22 & Non-Basis \\
\hline $\begin{array}{l}\text { Kota } \\
\text { Pekalongan }\end{array}$ & 1,56 & 0,01 & 0,00 & 0,00 & 0,00 & 0,02 & 0,00 & 0,00 & 0,20 & Non-Basis \\
\hline Kota Tegal & 1,57 & 0,00 & 0,00 & 0,00 & 0,00 & 0,00 & 0,00 & 0,00 & 0,20 & Non-Basis \\
\hline
\end{tabular}


Tabel 1 menjelaskan nilai rata - rata LQ tanaman pangan berdasarkan luas lahan pada 35 Kabupaten/Kota di Provinsi Jawa Tengah, hanya 12 daerah yang menjadi basis bagi tanaman pangan. Dari data tersebut dapat diketahui Kabupaten Wonogiri mempunyai nilai tertinggi dengan nilai $L Q>1$, hal ini berarti Kabupaten Wonogiri merupakan basis tanaman pangan di Provinsi Jawa Tengah berdasarkan atas luas lahan. Nilai LQ Kabupaten Wonogiri sebesar 2, merupakan rata - rata nilai LQ dari 8 tanaman pangan, keunggulan tanaman pangan pada daerah tersebut diantaranya padi ladang dengan nilai LQ 2,86, jagung nilai $L Q$ 1,17 , kedelai dengan nilai LQ 1,40, kacang tanah dengan nilai LQ 5,17 dan ubi kayu dengan nilai LQ 4,80.

Sementara Kabupaten Semarang berada pada berikutnya dari hasil LQ dengan nilai rata - rata 1,50 , dengan tanaman pangan unggulan berdasarkan luas lahan antara lain padi sawah, jagung, kacang tanah, dan ubi jalar. Daerah lain yang masuk dalam basis tanaman pangan unggulan berdasarkan luas lahan yaitu Kabupaten Wonosobo, Karanganyar, Jepara, Rembang, Kebumen, Grobogan, Demak, Banjarnegara, Pati dan Magelang.

Tabel 2. Rata - Rata Nilai LQ Tanaman Pangan Kabupaten/Kota di Provinsi Jawa Tengah Berdasarkan Produksi

\begin{tabular}{|c|c|c|c|c|c|c|c|c|c|c|}
\hline \multirow[b]{2}{*}{ Daerah } & \multicolumn{8}{|c|}{ LQ Produksi } & \multirow{2}{*}{$\begin{array}{c}\text { Rata } \\
- \\
\text { Rata }\end{array}$} & \multirow[b]{2}{*}{ Klasifikasi } \\
\hline & $\begin{array}{c}\text { Padi } \\
\text { Sawah }\end{array}$ & $\begin{array}{c}\text { Padi } \\
\text { Ladang }\end{array}$ & Jagung & Kedelai & $\begin{array}{l}\text { Kacang } \\
\text { Tanah }\end{array}$ & $\begin{array}{c}\text { Kacang } \\
\text { Hijau }\end{array}$ & $\begin{array}{c}\text { Ubi } \\
\text { Kayu }\end{array}$ & $\begin{array}{c}\text { Ubi } \\
\text { Jalar }\end{array}$ & & \\
\hline $\begin{array}{l}\text { Kabupaten } \\
\text { Semarang }\end{array}$ & 1,06 & 0,46 & 0,97 & 0,21 & 1,53 & 0,00 & 0,65 & 7,36 & 1,53 & Basis \\
\hline $\begin{array}{l}\text { Kabupaten } \\
\text { Karanganyar }\end{array}$ & 1,14 & 0,26 & 0,33 & 0,14 & 1,53 & 0,00 & 1,13 & 7,25 & 1,47 & Basis \\
\hline $\begin{array}{l}\text { Kabupaten } \\
\text { Grobogan }\end{array}$ & 0,83 & 0,58 & 2,22 & 4,24 & 0,16 & 3,32 & 0,09 & 0,05 & 1,44 & Basis \\
\hline $\begin{array}{l}\text { Kabupaten } \\
\text { Wonogiri }\end{array}$ & 0,38 & 2,15 & 0,86 & 0,97 & 3,84 & 0,01 & 2,93 & 0,13 & 1,41 & Basis \\
\hline $\begin{array}{l}\text { Kabupaten } \\
\text { Kebumen }\end{array}$ & 1,25 & 2,64 & 0,26 & 1,16 & 0,71 & 2,72 & 0,89 & 0,17 & 1,22 & Basis \\
\hline $\begin{array}{l}\text { Kabupaten } \\
\text { Batang }\end{array}$ & 1,12 & 0,00 & 0,95 & 0,13 & 0,30 & 0,00 & 0,61 & 6,48 & 1,20 & Basis \\
\hline $\begin{array}{l}\text { Kabupaten } \\
\text { Blora }\end{array}$ & 0,91 & 3,85 & 1,70 & 1,63 & 0,44 & 0,26 & 0,27 & 0,22 & 1,16 & Basis \\
\hline $\begin{array}{l}\text { Kabupaten } \\
\text { Demak }\end{array}$ & 0,90 & 0,96 & 2,16 & 0,10 & 0,03 & 4,76 & 0,02 & 0,22 & 1,14 & Basis \\
\hline $\begin{array}{l}\text { Kabupaten } \\
\text { Magelang }\end{array}$ & 1,28 & 0,00 & 0,57 & 0,00 & 0,34 & 0,00 & 0,57 & 5,86 & 1,08 & Basis \\
\hline $\begin{array}{l}\text { Kabupaten } \\
\text { Rembang }\end{array}$ & 0,79 & 2,05 & 1,36 & 1,05 & 0,73 & 0,67 & 1,17 & 0,71 & 1,07 & Basis \\
\hline $\begin{array}{l}\text { Kabupaten } \\
\text { Wonosobo }\end{array}$ & 0,59 & 0,03 & 0,97 & 0,01 & 0,10 & 0,00 & 2,33 & 4,35 & 1,05 & Basis \\
\hline $\begin{array}{l}\text { Kabupaten } \\
\text { Jepara }\end{array}$ & 0,71 & 0,52 & 0,52 & 0,06 & 3,14 & 0,01 & 2,51 & 0,28 & 0,97 & Non-Basis \\
\hline
\end{tabular}




\begin{tabular}{|c|c|c|c|c|c|c|c|c|c|c|}
\hline \multirow[b]{2}{*}{ Daerah } & \multicolumn{8}{|c|}{ LQ Produksi } & \multirow{2}{*}{$\begin{array}{c}\text { Rata } \\
- \\
\text { Rata }\end{array}$} & \multirow[b]{2}{*}{ Klasifikasi } \\
\hline & $\begin{array}{c}\text { Padi } \\
\text { Sawah }\end{array}$ & $\begin{array}{c}\text { Padi } \\
\text { Ladang }\end{array}$ & Jagung & Kedelai & $\begin{array}{c}\text { Kacang } \\
\text { Tanah }\end{array}$ & $\begin{array}{c}\text { Kacang } \\
\text { Hijau }\end{array}$ & $\begin{array}{c}\text { Ubi } \\
\text { Kayu }\end{array}$ & $\begin{array}{l}\text { Ubi } \\
\text { Jalar }\end{array}$ & & \\
\hline $\begin{array}{l}\text { Kabupaten } \\
\text { Sragen }\end{array}$ & 1,29 & 1,33 & 0,86 & 1,24 & 2,21 & 0,06 & 0,25 & 0,00 & 0,91 & Non-Basis \\
\hline $\begin{array}{l}\text { Kabupaten } \\
\text { Boyolali }\end{array}$ & 0,90 & 1,16 & 1,33 & 1,23 & 1,28 & 0,00 & 0,97 & 0,08 & 0,87 & Non-Basis \\
\hline $\begin{array}{l}\text { Kabupaten } \\
\text { Kudus }\end{array}$ & 1,25 & 0,38 & 0,51 & 0,22 & 0,54 & 2,55 & 0,86 & 0,64 & 0,87 & Non-Basis \\
\hline $\begin{array}{l}\text { Kabupaten } \\
\text { Sukoharjo }\end{array}$ & 1,54 & 0,00 & 0,18 & 1,32 & 3,48 & 0,02 & 0,33 & 0,01 & 0,86 & Non-Basis \\
\hline $\begin{array}{l}\text { Kabupaten } \\
\text { Cilacap }\end{array}$ & 1,46 & 1,61 & 0,15 & 1,21 & 0,24 & 0,98 & 0,51 & 0,73 & 0,86 & Non-Basis \\
\hline $\begin{array}{l}\text { Kabupaten } \\
\text { Kendal }\end{array}$ & 0,88 & 0,16 & 2,19 & 0,60 & 0,35 & 0,39 & 0,17 & 1,41 & 0,77 & Non-Basis \\
\hline $\begin{array}{l}\text { Kabupaten } \\
\text { Purworejo }\end{array}$ & 1,27 & 0,34 & 0,20 & 1,10 & 0,59 & 0,95 & 1,16 & 0,35 & 0,75 & Non-Basis \\
\hline $\begin{array}{l}\text { Kabupaten } \\
\text { Banjarnegara }\end{array}$ & 0,64 & 0,58 & 0,80 & 0,26 & 0,64 & 0,00 & 2,46 & 0,48 & 0,73 & Non-Basis \\
\hline $\begin{array}{l}\text { Kabupaten } \\
\text { Banyumas }\end{array}$ & 1,41 & 0,72 & 0,28 & 0,73 & 1,00 & 0,16 & 0,62 & 0,50 & 0,68 & Non-Basis \\
\hline $\begin{array}{l}\text { Kabupaten } \\
\text { Temanggung }\end{array}$ & 0,96 & 0,15 & 1,49 & 0,00 & 0,27 & 0,00 & 0,71 & 1,72 & 0,66 & Non-Basis \\
\hline $\begin{array}{l}\text { Kabupaten } \\
\text { Purbalingga }\end{array}$ & 1,11 & 0,17 & 0,58 & 1,01 & 0,32 & 0,00 & 1,28 & 0,77 & 0,65 & Non-Basis \\
\hline $\begin{array}{l}\text { Kabupaten } \\
\text { Brebes }\end{array}$ & 1,36 & 0,81 & 0,83 & 0,60 & 0,15 & 0,83 & 0,18 & 0,30 & 0,63 & Non-Basis \\
\hline Kota Salatiga & 1,09 & 0,00 & 0,23 & 0,05 & 0,05 & 0,00 & 1,74 & 1,58 & 0,59 & Non-Basis \\
\hline $\begin{array}{l}\text { Kabupaten } \\
\text { Klaten }\end{array}$ & 1,38 & 0,02 & 0,82 & 1,27 & 0,77 & 0,05 & 0,20 & 0,19 & 0,59 & Non-Basis \\
\hline $\begin{array}{l}\text { Kota } \\
\text { Semarang }\end{array}$ & 1,36 & 0,37 & 0,28 & 0,03 & 0,82 & 0,19 & 0,83 & 0,45 & 0,54 & Non-Basis \\
\hline $\begin{array}{l}\text { Kota } \\
\text { Surakarta }\end{array}$ & 1,57 & 0,62 & 0,00 & 0,00 & 1,54 & 0,00 & 0,47 & 0,00 & 0,53 & Non-Basis \\
\hline $\begin{array}{l}\text { Kabupaten } \\
\text { Pekalongan }\end{array}$ & 1,60 & 0,29 & 0,19 & 0,06 & 0,38 & 0,24 & 0,22 & 0,70 & 0,46 & Non-Basis \\
\hline $\begin{array}{l}\text { Kabupaten } \\
\text { Pemalang }\end{array}$ & 1,54 & 0,46 & 0,39 & 0,43 & 0,10 & 0,01 & 0,16 & 0,46 & 0,45 & Non-Basis \\
\hline $\begin{array}{l}\text { Kabupaten } \\
\text { Tegal }\end{array}$ & 1,28 & 0,08 & 1,23 & 0,07 & 0,10 & 0,02 & 0,10 & 0,29 & 0,40 & Non-Basis \\
\hline $\begin{array}{l}\text { Kota } \\
\text { Magelang }\end{array}$ & 1,74 & 0,00 & 0,01 & 0,00 & 0,17 & 0,00 & 0,07 & 0,00 & 0,25 & Non-Basis \\
\hline Kota Tegal & 1,76 & 0,04 & 0,00 & 0,00 & 0,00 & 0,00 & 0,00 & 0,00 & 0,23 & Non-Basis \\
\hline $\begin{array}{l}\text { Kota } \\
\text { Pekalongan }\end{array}$ & 1,76 & 0,01 & 0,00 & 0,00 & 0,00 & 0,01 & 0,00 & 0,00 & 0,22 & Non-Basis \\
\hline
\end{tabular}

Sumber: Hasil Pengolahan Data (2021) 
Tabel 2 menjelaskan nilai rata - rata LQ tanaman pangan berdasarkan produksi pada 35 Kabupaten/Kota di Provinsi Jawa Tengah, terdapat 11 Kabupaten/Kota yang menjadi daerah basis bagi sektor tanaman pangan. Dari data tersebut dapat diketahui bahwa Kabupaten Semarang menempati urutan pertama bagi daerah basis tanaman pangan berdasarkan produksi. Nilai LQ yang diperoleh Kabupaten Semarang diatas 1, dengan nilai sebesar 1,53. Komoditas tanaman pangan yang menjadi unggulan di daerah tersebut diantaranya, padi sawah dengan nilai $L Q 1,06$, kacang tanah dengan nilai $L Q 1,53$ dan ubi jalar dengan nilai $L Q$ 7,36 .

Daerah berikutnya yang menjadi basis tanaman pangan unggulan berdasarkan produksi-nya, Kabupaten Karanganyar, Grobogan, Wonogiri, Kebumen, Batang, Blora, Demak, Magelang, Rembang dan Wonosobo.

Tabel 3. Rata - Rata Nilai IS Tanaman Pangan Kabupaten/Kota di Provinsi Jawa Tengah Berdasarkan Luas Lahan

\begin{tabular}{|c|c|c|c|c|c|c|c|c|c|}
\hline \multirow[b]{2}{*}{ Daerah } & \multicolumn{8}{|c|}{ IS Luas Lahan } & \multirow{2}{*}{$\begin{array}{l}\text { Rata - } \\
\text { Rata }\end{array}$} \\
\hline & $\begin{array}{c}\text { Padi } \\
\text { Sawah }\end{array}$ & $\begin{array}{c}\text { Padi } \\
\text { Ladang }\end{array}$ & Jagung & Kedelai & $\begin{array}{l}\text { Kacang } \\
\text { Tanah }\end{array}$ & $\begin{array}{c}\text { Kacang } \\
\text { Hijau }\end{array}$ & $\begin{array}{c}\text { Ubi } \\
\text { Kayu }\end{array}$ & $\begin{array}{l}\text { Ubi } \\
\text { Jalar }\end{array}$ & \\
\hline $\begin{array}{l}\text { Kabupaten } \\
\text { Cilacap }\end{array}$ & 0,10 & 0,01 & 0,09 & 0,01 & 0,01 & 0,01 & 0,01 & 0,00 & 0,03 \\
\hline $\begin{array}{l}\text { Kabupaten } \\
\text { Banyumas }\end{array}$ & 0,11 & 0,01 & 0,08 & 0,00 & 0,00 & 0,01 & 0,01 & 0,00 & 0,03 \\
\hline $\begin{array}{l}\text { Kabupaten } \\
\text { Purbalingga }\end{array}$ & 0,06 & 0,01 & 0,03 & 0,02 & 0,01 & 0,02 & 0,00 & 0,00 & 0,02 \\
\hline $\begin{array}{l}\text { Kabupaten } \\
\text { Banjarnegara }\end{array}$ & 0,06 & 0,00 & 0,03 & 0,01 & 0,01 & 0,02 & 0,05 & 0,00 & 0,02 \\
\hline $\begin{array}{l}\text { Kabupaten } \\
\text { Kebumen }\end{array}$ & 0,04 & 0,01 & 0,08 & 0,01 & 0,00 & 0,03 & 0,01 & 0,00 & 0,02 \\
\hline $\begin{array}{l}\text { Kabupaten } \\
\text { Purworejo }\end{array}$ & 0,09 & 0,01 & 0,08 & 0,01 & 0,00 & 0,01 & 0,00 & 0,00 & 0,02 \\
\hline $\begin{array}{l}\text { Kabupaten } \\
\text { Wonosobo }\end{array}$ & 0,08 & 0,01 & 0,10 & 0,01 & 0,01 & 0,02 & 0,03 & 0,01 & 0,03 \\
\hline $\begin{array}{l}\text { Kabupaten } \\
\text { Magelang }\end{array}$ & 0,09 & 0,01 & 0,03 & 0,01 & 0,01 & 0,02 & 0,01 & 0,01 & 0,02 \\
\hline $\begin{array}{l}\text { Kabupaten } \\
\text { Boyolali }\end{array}$ & 0,05 & 0,00 & 0,05 & 0,01 & 0,00 & 0,02 & 0,00 & 0,00 & 0,02 \\
\hline $\begin{array}{l}\text { Kabupaten } \\
\text { Klaten }\end{array}$ & 0,09 & 0,01 & 0,04 & 0,00 & 0,00 & 0,01 & 0,02 & 0,00 & 0,02 \\
\hline $\begin{array}{l}\text { Kabupaten } \\
\text { Sukoharjo }\end{array}$ & 0,10 & 0,01 & 0,09 & 0,00 & 0,02 & 0,02 & 0,01 & 0,00 & 0,03 \\
\hline $\begin{array}{l}\text { Kabupaten } \\
\text { Wonogiri }\end{array}$ & 0,18 & 0,03 & 0,02 & 0,01 & 0,06 & 0,02 & 0,09 & 0,00 & 0,05 \\
\hline $\begin{array}{l}\text { Kabupaten } \\
\text { Karanganyar }\end{array}$ & 0,08 & 0,01 & 0,06 & 0,01 & 0,01 & 0,02 & 0,00 & 0,01 & 0,02 \\
\hline $\begin{array}{l}\text { Kabupaten } \\
\text { Sragen }\end{array}$ & 0,04 & 0,00 & 0,02 & 0,00 & 0,01 & 0,01 & 0,02 & 0,00 & 0,01 \\
\hline
\end{tabular}




\begin{tabular}{|c|c|c|c|c|c|c|c|c|c|}
\hline \multirow[b]{2}{*}{ Daerah } & \multicolumn{8}{|c|}{ IS Luas Lahan } & \multirow{2}{*}{$\begin{array}{l}\text { Rata } \\
\text { Rata }\end{array}$} \\
\hline & $\begin{array}{c}\text { Padi } \\
\text { Sawah }\end{array}$ & $\begin{array}{c}\text { Padi } \\
\text { Ladang }\end{array}$ & Jagung & Kedelai & $\begin{array}{c}\text { Kacang } \\
\text { Tanah }\end{array}$ & $\begin{array}{c}\text { Kacang } \\
\text { Hijau }\end{array}$ & $\begin{array}{c}\text { Ubi } \\
\text { Kayu }\end{array}$ & $\begin{array}{l}\text { Ubi } \\
\text { Jalar }\end{array}$ & \\
\hline $\begin{array}{l}\text { Kabupaten } \\
\text { Grobogan }\end{array}$ & 0,11 & 0,01 & 0,10 & 0,02 & 0,01 & 0,03 & 0,02 & 0,00 & 0,04 \\
\hline $\begin{array}{l}\text { Kabupaten } \\
\text { Blora }\end{array}$ & 0,07 & 0,03 & 0,08 & 0,01 & 0,01 & 0,01 & 0,02 & 0,00 & 0,03 \\
\hline $\begin{array}{l}\text { Kabupaten } \\
\text { Rembang }\end{array}$ & 0,08 & 0,01 & 0,07 & 0,01 & 0,00 & 0,00 & 0,01 & 0,00 & 0,02 \\
\hline Kabupaten Pati & 0,01 & 0,00 & 0,03 & 0,00 & 0,01 & 0,02 & 0,03 & 0,00 & 0,01 \\
\hline $\begin{array}{l}\text { Kabupaten } \\
\text { Kudus }\end{array}$ & 0,05 & 0,01 & 0,05 & 0,01 & 0,01 & 0,03 & 0,00 & 0,00 & 0,02 \\
\hline $\begin{array}{l}\text { Kabupaten } \\
\text { Jepara }\end{array}$ & 0,02 & 0,00 & 0,04 & 0,01 & 0,04 & 0,02 & 0,04 & 0,00 & 0,02 \\
\hline $\begin{array}{l}\text { Kabupaten } \\
\text { Demak }\end{array}$ & 0,01 & 0,00 & 0,02 & 0,01 & 0,01 & 0,07 & 0,02 & 0,00 & 0,02 \\
\hline $\begin{array}{l}\text { Kabupaten } \\
\text { Semarang }\end{array}$ & 0,02 & 0,01 & 0,01 & 0,01 & 0,00 & 0,02 & 0,01 & 0,01 & 0,01 \\
\hline $\begin{array}{l}\text { Kabupaten } \\
\text { Temanggung }\end{array}$ & 0,06 & 0,01 & 0,12 & 0,01 & 0,01 & 0,02 & 0,01 & 0,00 & 0,03 \\
\hline $\begin{array}{l}\text { Kabupaten } \\
\text { Kendal }\end{array}$ & 0,05 & 0,01 & 0,10 & 0,00 & 0,01 & 0,01 & 0,02 & 0,00 & 0,03 \\
\hline $\begin{array}{l}\text { Kabupaten } \\
\text { Batang }\end{array}$ & 0,08 & 0,01 & 0,02 & 0,01 & 0,01 & 0,02 & 0,01 & 0,00 & 0,02 \\
\hline $\begin{array}{l}\text { Kabupaten } \\
\text { Pekalongan }\end{array}$ & 0,14 & 0,01 & 0,08 & 0,01 & 0,01 & 0,01 & 0,02 & 0,00 & 0,03 \\
\hline $\begin{array}{l}\text { Kabupaten } \\
\text { Pemalang }\end{array}$ & 0,12 & 0,01 & 0,06 & 0,01 & 0,01 & 0,02 & 0,02 & 0,00 & 0,03 \\
\hline $\begin{array}{l}\text { Kabupaten } \\
\text { Tegal }\end{array}$ & 0,06 & 0,01 & 0,02 & 0,01 & 0,01 & 0,02 & 0,02 & 0,00 & 0,02 \\
\hline $\begin{array}{l}\text { Kabupaten } \\
\text { Brebes }\end{array}$ & 0,07 & 0,01 & 0,03 & 0,01 & 0,01 & 0,00 & 0,02 & 0,00 & 0,02 \\
\hline Kota Magelang & 0,17 & 0,01 & 0,10 & 0,01 & 0,01 & 0,02 & 0,02 & 0,00 & 0,04 \\
\hline Kota Surakarta & 0,11 & 0,01 & 0,10 & 0,01 & 0,02 & 0,02 & 0,01 & 0,00 & 0,04 \\
\hline Kota Salatiga & 0,09 & 0,01 & 0,06 & 0,01 & 0,01 & 0,02 & 0,01 & 0,00 & 0,03 \\
\hline Kota Semarang & 0,10 & 0,01 & 0,06 & 0,01 & 0,00 & 0,01 & 0,01 & 0,00 & 0,03 \\
\hline $\begin{array}{l}\text { Kota } \\
\text { Pekalongan }\end{array}$ & 0,18 & 0,01 & 0,10 & 0,01 & 0,01 & 0,02 & 0,02 & 0,00 & 0,05 \\
\hline Kota Tegal & 0,18 & 0,01 & 0,10 & 0,01 & 0,01 & 0,02 & 0,02 & 0,00 & 0,05 \\
\hline
\end{tabular}

Sumber: Hasil Pengolahan Data (2021)

Tabel 3 menjelaskan indeks spesialisasi regional dapat diketahui bahwa keseluruhan Kabupaten/Kota di Provinsi Jawa Tengah nilai rata - ratanya berada pada angka 0, hal ini berarti antara Kabupaten / Kota terhadap Provinsi Jawa Tengah tidak ada spesialisasi yang menjadi unggulan dari Kabupaten/Kota. 
Tabel 4. Rata - Rata Nilai IS Tanaman Pangan Kabupaten/Kota di Provinsi Jawa Tengah Berdasarkan Produksi

\begin{tabular}{|c|c|c|c|c|c|c|c|c|c|}
\hline \multirow[b]{2}{*}{ Daerah } & \multicolumn{8}{|c|}{ IS Produksi } & \multirow{2}{*}{$\begin{array}{l}\text { Rata } \\
\text { Rata }\end{array}$} \\
\hline & $\begin{array}{c}\text { Padi } \\
\text { Sawah }\end{array}$ & $\begin{array}{c}\text { Padi } \\
\text { Ladang }\end{array}$ & Jagung & Kedelai & $\begin{array}{l}\text { Kacang } \\
\text { Tanah }\end{array}$ & $\begin{array}{c}\text { Kacang } \\
\text { Hijau }\end{array}$ & $\begin{array}{c}\text { Ubi } \\
\text { Kayu }\end{array}$ & $\begin{array}{l}\text { Ubi } \\
\text { Jalar }\end{array}$ & \\
\hline $\begin{array}{l}\text { Kabupaten } \\
\text { Cilacap }\end{array}$ & 0,13 & 0,01 & 0,09 & 0,00 & 0,00 & 0,00 & 0,04 & 0,00 & 0,03 \\
\hline $\begin{array}{l}\text { Kabupaten } \\
\text { Banyumas }\end{array}$ & 0,13 & 0,01 & 0,06 & 0,00 & 0,00 & 0,00 & 0,06 & 0,00 & 0,03 \\
\hline $\begin{array}{l}\text { Kabupaten } \\
\text { Purbalingga }\end{array}$ & 0,03 & 0,01 & 0,04 & 0,01 & 0,00 & 0,00 & 0,03 & 0,00 & 0,01 \\
\hline $\begin{array}{l}\text { Kabupaten } \\
\text { Banjarnegara }\end{array}$ & 0,10 & 0,00 & 0,02 & 0,00 & 0,00 & 0,00 & 0,13 & 0,00 & 0,03 \\
\hline $\begin{array}{l}\text { Kabupaten } \\
\text { Kebumen }\end{array}$ & 0,07 & 0,01 & 0,07 & 0,00 & 0,00 & 0,01 & 0,02 & 0,00 & 0,02 \\
\hline $\begin{array}{l}\text { Kabupaten } \\
\text { Purworejo }\end{array}$ & 0,08 & 0,01 & 0,08 & 0,00 & 0,00 & 0,00 & 0,02 & 0,00 & 0,02 \\
\hline $\begin{array}{l}\text { Kabupaten } \\
\text { Wonosobo }\end{array}$ & 0,12 & 0,01 & 0,02 & 0,00 & 0,00 & 0,00 & 0,12 & 0,02 & 0,04 \\
\hline $\begin{array}{l}\text { Kabupaten } \\
\text { Magelang }\end{array}$ & 0,08 & 0,01 & 0,04 & 0,00 & 0,00 & 0,00 & 0,04 & 0,02 & 0,03 \\
\hline $\begin{array}{l}\text { Kabupaten } \\
\text { Boyolali }\end{array}$ & 0,03 & 0,00 & 0,04 & 0,00 & 0,00 & 0,00 & 0,02 & 0,00 & 0,01 \\
\hline $\begin{array}{l}\text { Kabupaten } \\
\text { Klaten }\end{array}$ & 0,11 & 0,01 & 0,02 & 0,00 & 0,00 & 0,00 & 0,07 & 0,00 & 0,03 \\
\hline $\begin{array}{l}\text { Kabupaten } \\
\text { Sukoharjo }\end{array}$ & 0,15 & 0,01 & 0,08 & 0,00 & 0,01 & 0,00 & 0,06 & 0,00 & 0,04 \\
\hline $\begin{array}{l}\text { Kabupaten } \\
\text { Wonogiri }\end{array}$ & 0,17 & 0,01 & 0,02 & 0,00 & 0,01 & 0,00 & 0,18 & 0,00 & 0,05 \\
\hline $\begin{array}{l}\text { Kabupaten } \\
\text { Karanganyar }\end{array}$ & 0,04 & 0,01 & 0,07 & 0,00 & 0,00 & 0,00 & 0,01 & 0,03 & 0,02 \\
\hline $\begin{array}{l}\text { Kabupaten } \\
\text { Sragen }\end{array}$ & 0,08 & 0,00 & 0,01 & 0,00 & 0,00 & 0,00 & 0,07 & 0,00 & 0,02 \\
\hline $\begin{array}{l}\text { Kabupaten } \\
\text { Grobogan }\end{array}$ & 0,05 & 0,00 & 0,13 & 0,01 & 0,00 & 0,01 & 0,08 & 0,00 & 0,04 \\
\hline $\begin{array}{l}\text { Kabupaten } \\
\text { Blora }\end{array}$ & 0,02 & 0,02 & 0,07 & 0,00 & 0,00 & 0,00 & 0,07 & 0,00 & 0,02 \\
\hline $\begin{array}{l}\text { Kabupaten } \\
\text { Rembang }\end{array}$ & 0,06 & 0,01 & 0,04 & 0,00 & 0,00 & 0,00 & 0,02 & 0,00 & 0,02 \\
\hline $\begin{array}{l}\text { Kabupaten } \\
\text { Pati }\end{array}$ & 0,08 & 0,00 & 0,05 & 0,00 & 0,00 & 0,00 & 0,14 & 0,00 & 0,04 \\
\hline $\begin{array}{l}\text { Kabupaten } \\
\text { Kudus }\end{array}$ & 0,07 & 0,01 & 0,05 & 0,00 & 0,00 & 0,00 & 0,02 & 0,00 & 0,02 \\
\hline $\begin{array}{l}\text { Kabupaten } \\
\text { Jepara }\end{array}$ & 0,08 & 0,00 & 0,05 & 0,00 & 0,01 & 0,00 & 0,14 & 0,00 & 0,04 \\
\hline $\begin{array}{l}\text { Kabupaten } \\
\text { Demak }\end{array}$ & 0,09 & 0,00 & 0,06 & 0,00 & 0,00 & 0,01 & 0,09 & 0,00 & 0,03 \\
\hline
\end{tabular}




\begin{tabular}{|c|c|c|c|c|c|c|c|c|c|}
\hline \multirow[b]{2}{*}{ Daerah } & \multicolumn{8}{|c|}{ IS Produksi } & \multirow{2}{*}{$\begin{array}{l}\text { Rata } \\
\text { Rata }\end{array}$} \\
\hline & $\begin{array}{c}\text { Padi } \\
\text { Sawah }\end{array}$ & $\begin{array}{c}\text { Padi } \\
\text { Ladang }\end{array}$ & Jagung & Kedelai & $\begin{array}{c}\text { Kacang } \\
\text { Tanah }\end{array}$ & $\begin{array}{c}\text { Kacang } \\
\text { Hijau }\end{array}$ & $\begin{array}{l}\text { Ubi } \\
\text { Kayu }\end{array}$ & $\begin{array}{l}\text { Ubi } \\
\text { Jalar }\end{array}$ & \\
\hline $\begin{array}{l}\text { Kabupaten } \\
\text { Semarang }\end{array}$ & 0,02 & 0,00 & 0,02 & 0,00 & 0,00 & 0,00 & 0,03 & 0,03 & 0,01 \\
\hline $\begin{array}{l}\text { Kabupaten } \\
\text { Temanggung }\end{array}$ & 0,02 & 0,01 & 0,06 & 0,00 & 0,00 & 0,00 & 0,03 & 0,00 & 0,02 \\
\hline $\begin{array}{l}\text { Kabupaten } \\
\text { Kendal }\end{array}$ & 0,04 & 0,01 & 0,12 & 0,00 & 0,00 & 0,00 & 0,08 & 0,00 & 0,03 \\
\hline $\begin{array}{l}\text { Kabupaten } \\
\text { Batang }\end{array}$ & 0,03 & 0,01 & 0,02 & 0,00 & 0,00 & 0,00 & 0,04 & 0,02 & 0,02 \\
\hline $\begin{array}{l}\text { Kabupaten } \\
\text { Pekalongan }\end{array}$ & 0,16 & 0,01 & 0,08 & 0,00 & 0,00 & 0,00 & 0,07 & 0,00 & 0,04 \\
\hline $\begin{array}{l}\text { Kabupaten } \\
\text { Pemalang }\end{array}$ & 0,15 & 0,00 & 0,06 & 0,00 & 0,00 & 0,00 & 0,08 & 0,00 & 0,04 \\
\hline $\begin{array}{l}\text { Kabupaten } \\
\text { Tegal }\end{array}$ & 0,07 & 0,01 & 0,04 & 0,00 & 0,00 & 0,00 & 0,08 & 0,00 & 0,03 \\
\hline $\begin{array}{l}\text { Kabupaten } \\
\text { Brebes }\end{array}$ & 0,10 & 0,00 & 0,02 & 0,00 & 0,00 & 0,00 & 0,08 & 0,00 & 0,03 \\
\hline $\begin{array}{l}\text { Kota } \\
\text { Magelang }\end{array}$ & 0,21 & 0,01 & 0,10 & 0,00 & 0,00 & 0,00 & 0,08 & 0,00 & 0,05 \\
\hline $\begin{array}{l}\text { Kota } \\
\text { Surakarta }\end{array}$ & 0,14 & 0,01 & 0,10 & 0,00 & 0,00 & 0,00 & 0,07 & 0,00 & 0,04 \\
\hline Kota Salatiga & 0,04 & 0,01 & 0,08 & 0,00 & 0,00 & 0,00 & 0,06 & 0,01 & 0,03 \\
\hline $\begin{array}{l}\text { Kota } \\
\text { Semarang }\end{array}$ & 0,10 & 0,01 & 0,07 & 0,00 & 0,00 & 0,00 & 0,02 & 0,00 & 0,03 \\
\hline $\begin{array}{l}\text { Kota } \\
\text { Pekalongan }\end{array}$ & 0,22 & 0,01 & 0,10 & 0,00 & 0,00 & 0,00 & 0,09 & 0,00 & 0,05 \\
\hline Kota Tegal & 0,22 & 0,01 & 0,10 & 0,00 & 0,00 & 0,00 & 0,09 & 0,00 & 0,05 \\
\hline
\end{tabular}

Tabel 4 menjelaskan nilai rata - rata indeks spesialisasi tanaman pangan berdasarkan produksi pada Kabupaten/Kota di Provinsi Jawa Tengah. Dari hasil yang diperoleh, angka indeks spesialisasi tanaman pangan berdasarkan produksi berada pada angka 0 , hal ini berarti bahwa antara Kabupaten/Kota terhadap Provinsi Jawa Tengah tidak terdapat spesialisasi dari segi tanaman pangan berdasarkan produksinya.

\section{Kesimpulan}

Dalam menentukan tanaman pangan unggulan dalam penelitian ini, menggunakan metode location quotient $(L Q)$, berdasarkan hasil nilai rata - rata $L Q$ berdasarkan luas lahan dimana nilai $L Q>1$, hanya 12 daerah diantaranya Kabupaten Wonogiri, Semarang, Wonosobo, Karanganyar, Jepara, Rembang, Kebumen, Grobogan, Demak, Banjarnegara, Pati dan Magelang. Hal ini berarti dari segi kemanfaatan lahan dalam produksi tanaman pangan seperti padi sawah, padi ladang, jagung, kedelai, kacang tanah, kacang hijau, ubi kayu, dan ubi jalar 
sudah baik, dimana mereka mampu memenuhi kebutuhan daerah mereka sendiri serta tidak menutup kemungkinan untuk melakukan ekspor ke daerah lain yang membutuhkan.

Sementara jika melihat hasil nilai rata - rata LQ tanaman pangan berdasarkan produksi-nya, nilai LQ yang melebihi angka 1 hanya 11 Kabupaten/Kota yang merupakan basis tanaman pangan di Provinsi Jawa Tengah. Hal ini berarti kesebelas daerah tersebut sudah mampu untuk memenuhi kebutuhan daerah mereka sendiri serta juga mampu melakukan ekspor ke daerah lain yang membutuhkan.

Untuk daerah yang bukan merupakan basis tanaman pangan pada Provinsi Jawa Tengah, maka hal yang bisa dilakukan adalah mulai melakukan spesialisasi tanaman pangan yang sesuai dengan kebutuhan serta kondisi daerahnya. Hal ini penting untuk dilakukan untuk memenuhi kebutuhan masyarakat terhadap makanan pokok yang saat ini dibutuhkan, serta dapat meningkatkan pendapatan bagi daerah tersebut.

\section{Daftar Pustaka}

Mahroji, D., \& Indrawati, M. (2020). Analisis Sektor Unggulan Dan Spesialisasi Regional Kota Bandar Lampung. Jurnal Ekobis: Ekonomi Bisnis \& Manajemen. Https://Doi.Org/10.37932/J.E.V9i1.44

Oktavia, Z., Hadi Darwanto, D., \& Hartono, S. (2015). Sektor Pertanian Unggulan Di Sumatera Selatan. Agraris: Journal Of Agribusiness And Rural Development Research. Https://Doi.Org/10.18196/Agr.129

Rohman, A., \& Maharani, A. D. (2018). Proyeksi Kebutuhan Konsumsi Pangan Beras Di Daerah Istimewa Yogyakarta. Caraka Tani: Journal Of Sustainable Agriculture. Https://Doi.Org/10.20961/Carakatani.V32i1.12144

Tan, K. G., Rao, K., \& Rajan, R. (2015). How Productive Is The Agricultural Sector Across Indian States? International Journal Of Development Issues. Https://Doi.Org/10.1108/ljdi01-2015-0007

Taufiqurahman, E., \& Widodo, T. (2011). Modified Lq And Dynamic Economic Base. Fokus Ekonomi.

Tuminem, F. (2019). Peranan Komoditas Tanaman Pangan Unggulan Terhadap Kesempatan Kerja Dan Pendapatan Di Kabupaten Sukoharjo (Analisis Input-Output). Jurnal Pangan. Https://Doi.Org/10.33964/Jp.V27i3.397 